\title{
PUTUSAN MAHKAMAH KONSTITUSI NOMOR 93/PUU-X/2012 DAN KEWENANGAN PENGADILAN AGAMA DALAM PENYELESAIAN SENGKETA EKONOMI SYARIAH
}

\author{
Dody Sulistio \\ Universitas Islam Negeri Sultan Thaha Saifudin Jambi \\ dody@uinjambi.ac.id
}

\begin{abstract}
Abstrak. Dengan diputuskannya perkara Nomor 93/PUU-X/2012 oleh Mahkamah Konstitusi, tidak ada lagi dualisme kewenangan penyelesaian sengketa ekonomi syariah. Konsekuensi konstitusionalnya, Pengadilan Agama menjadi satu-satunya pengadilan yang berwenang menyelesaikan sengketa ekonomi syariah. Namun menjadi catatan penting bahwa penentuan pilihan forum hukum bergantung pada kesepakatan para pihak yang tertuang dalam klausul. Para pihak dapat juga memilih alternatif lain untuk menyelesaikan sengketa ekonomi syariah di luar jalur pengadilan, seperti Basyarnas. Penyelesaian sengketa ekonomi syariah melalui Badan Arbitrase Syariah Nasional (BASYARNAS) saat ini mulai diminati masyarakat karena penyelesaian sengketa di BASYARNAS lebih mengedapankan perdamaianmelalui musyawarah. Namun, undang-undang yang mengatur terkait kewenangan pengadilan terhadap eksekusi putusan BASYARNAS masih mengalami tumpang tindih peraturan. Penelitian ini berfungsi untuk mengetahui penyebab terjadinya dualisme peraturan tentang eksekusi putusan BASYARNAS dan mengetahui akibat hukum adanya dualisme tersebut. Peradilan Agama (PA) sebagai produk legislasi pertama memberikan kompetensi kepada PA dalam menyelesaikan sengketa ekonomi syariah dan diperkuat dengan adanya UU Perbankan syariah, semestinya Peradilan Agama sudah secara praktis memiliki wewenang menyelesaikan sengketa ekonomi syariah. Hasil dari penelitian ini menunjukkan bahwa adanya dualisme terjadi karena adanya UU No.30 Tahun 1999 yang membatasi kompetensi absolut PA sebagai lembaga yang berwenang menyelesaikan sengketa ekonomi syariah.PERMA No.14 Tahun 2016 telah memberikan kepastian hukum bahwa eksekusi dari putusan BASYARNAS dilaksanakan di PA. PERMA ini merupakan sebuah kemajuan karena telah mengembalikan ruh kesyariahan dari putusan BASYARNAS terkait sengketa dagang atau ekonomi syariah yang pada akhirnya eksekusi dilaksanakan di Pengadilan Agama.
\end{abstract}

\section{Kata Kunci: Basyarnas, Eksekusi, Putusan}

\section{PENDAHULUAN}

Geliat ekonomi global saat ini sedang menjadi sorotan dalam dunia internasional. Ekonomi global yang diidentikkan dengan sistem ekonomi kapitalis 
sedang mengalami gocangan, demonstrasi terjadi di berbagai belahan dunia menggugat dan menentang kebijakan ekonomi kapitalis, yang mengutamakan hak individu ini. Artinya, masyarakat dunia sudah mengalami kemunduran ekonomi (dalam perpektif kesejahteraan sosial ekonomi) dengan sistem kapitalis ini. Hal Ini membuktikan masyarakat dunia sudah tidak sepakat lagi dengan sistem ekonomi kapitalis. Kebijakan Ekonomi Kapitalis di beberapa negara Eropa berbentuk ekonomi global menjadikan ketimpangan perekenomian semakin lebar

Tidak bisa dipungkiri, bahwa Ekonomi kapitalisme telah begitu banyak memberikan hasil yang positif bagi peradaban umat manusia. Seperti kemudahan fasilitas hidup, perkembangan teknologi, variasi produk menunjukkan peranya yang signitifikan dalam sejarah peradaban umat manusia. Namun selama abad 20, yaitu masa pembangunan ekonomi kapitalisme, selain megahnya pembangunan fisik ekonomi, ternyata terdapat bukti dan data-data yang sangat jelas yang menunjukkan bahwa sistem kapitalisme memberikan goncangan-goncangan ekonomi dan implikasi-implikasi negatif. Jeratan hutang dihampir seluruh Negara berkembang, kemiskinan yang terus meluas di dunia ketiga, dan krisis ekonomi khususnya sektor keuangan tak putus-putusnya menyerang dunia.Dalam interaksi ekonomi internasional terlihat bagaimana sistem ekonomi kapitalis menciptakan kondisi kompetisi yang tidak sehat dalam percaturan ekonomi dunia, bahkan wujud kecenderungan eksploitasi dari sekelompok negara terhadap negara lain.

Kebangkitan kembali ilmu Ekonomi Syari'ah merupakan sebuah jawaban atas kebutuhan terhadap ilmu ekonomi yang humanis. Dengan memuat nila-nilai ajaran Islam, Ilmu Ekonomi Islam diyakini akan mampu mensejahterakan umat manusia denganlebih baik. ${ }^{1}$ Syariah Islam termasuk syariah perekonomian mempunyai komitmen untuk dipraktekan dalam rangka menjadi sebab kebahagiaan dan kesejahteraan hidup. Demikian juga tujuan syariah Islam dalam bidang

\footnotetext{
${ }^{1}$ Yususf Qardhawi, Norma dan Etika Ekonomi Islam, alih bahasa: Zainal Arifin, Lc dan Dra. Dahlia Husin. (Jakarta: Gema Insani Press, 2001), hlm 67
} 
perekonomian yaitu untuk menciptakan keadilan dan kesejahteraan dalam berbisnis. $^{2}$

Dalam dunia ekonomi,-termasuk ekonomi Syariah- potensi terjadinya sengketa sangat mungkin terjadi. Penyelesaian sengketa ekonomi syariah dapat melalui jalur litigasi dan jalur nonlitigasi. Dalam hal penyelesaian sengketa Ekonomi Syari'ah melalui jalur litigasi dapat diajukan ke Pengadila Agama yang dalam hal ini adalah lembaga Peradilan yang berwenang untuk memutuskan perkara sengketa Syari'ah..

Adapun penyelesaian sengketa syariah dengan jalur non litigasi salah satunya adalah melalui Badan Arbitrase Syariah Nasional (Basyarnas). Di dalamnya menangani sengketa bisnis syariah, perbankan syariah, maupun lembaga keuangan syariah lainnya. Hal ini diperkuat dengan disahkannya UU Nomor 21 Tahun 2008 tentang Perbankan Syariah. Pada Pasal 55 ayat (2) dinyatakan,

"Dalam hal para pihak telah memperjanjikan penyelesaian sengketa selain sebagaimana dimaksud pada ayat (1), penyelesaian sengketa dilakukan sesuai dengan isi akad."

Bahwa dalam penjelasan Pasal 55, yang dimaksud dengan penyelesaian sengketa dilakukan sesuai dengan isi akad adalah melalui upaya sebagai berikut: a. musyawarah, b. mediasi perbankan, c. melalui Badan Arbitrase Syariah Nasional (Basyarnas) atau lembaga arbitrase lain dan/atau, d. melalui pengadilan dalam lingkungan peradilan umum. ${ }^{6}$ Dari Undang-Undang tersebut kemudian muncul

\footnotetext{
${ }^{2}$ Fazlur Rahman, Doktrin Ekonomi Islam. (Jakarta: Dana Bhakti Prima Yasa, 1995), hlm 76

3 Pasal 49 huruf (i) UU Nomor 3 Tahun 2006 Tentang Perubahan Atas UU Nomor 7 Tahun 1989 Tentang Peradilan Agama. Pasal 49 beserta penjelasanya Undang-Undang Nomor 3 Tahun 2006 yang telah diubah dengan Undang-Undang Nomor 50 tahun 2009 tentang Peradilan Agama yang berbunyi, "Pengadilan agama bertugas dan berwenang memeriksa, memutus, dan menyelesaikan perkara di tingkat pertama antara orang-orang yang beragama Islam di bidang: a. perkawinan; b. waris; c. wasiat; d. hibab; e. wakaf; f. zakat; g. infaq; h. shadaqab; dan i. ekonomi syari'ah. Penjelasan: Yang imaksud dengan "ekonomi syari'ab" adalab perbuatan atau kegiatan usaba yang dilaksanakan menurut prinsip syari'ah, antara lain meliputi: a. bank syari'ab; b. lembaga keuangan mikro syariah. c. asuransi syari'ab; d. reasuransi syariah; e. reksa dana syariah; f. obligasi syariah dan surat berbarga berjangka menengah syariab; g. sekuritas syariah; $h$. pembiayaan syariah; $i$. pegadaian syari'ah; j. dana pensiun lembaga keuangan syari'ah; dan k. bisnis syari'ah.

${ }_{4}^{4}$ Pasal 60 ayat (1) UU Nomor 48 Tahun 2009 Tentang Kekuasan Kehakiman.

5 Pasal 58 dan Pasal 59 UU Nomor 48 Tahun 2009 Tentang Kekuasan Kehakiman. Kemudian dalam penjelasan Pasal 59 ayat (1) dijelaskan yang dimaksud dengan "arbitrase" dalam ketentuan ini termasuk juga arbitrase syariah (BASYARNAS).

${ }^{6}$ UU Nomor 21 Tahun 2008 Tentang Perbankan Syariah.
} 
persoalan konstitusionalitas yang membingungkan para pihak karena tidak adanya ketegasan dalam hal ini kepastian hukum untuk menyelesaikan sengketa ekonomi syariah. Adanya pilihan hukum tersebut tidak hanya menyebabkan kerugian bagi nasabah, tetapi juga pihak unit usaha syariah. ${ }^{7}$

Dengan diputuskannya perkara Nomor 93/PUU-X/2012 oleh Mahkamah Konstitusi, tidak ada lagi dualisme kewenangan penyelesaian sengketa ekonomi syariah. Konsekuensi konstitusionalnya, Pengadilan Agama menjadi satu-satunya pengadilan yang berwenang menyelesaikan sengketa ekonomi syariah. ${ }^{8}$ Namun menjadi catatan penting bahwa penentuan pilihan forum hukum bergantung pada kesepakatan para pihak yang tertuang dalam klausul. Para pihak dapat juga memilih alternatif lain untuk menyelesaikan sengketa ekonomi syariah di luar jalur pengadilan, seperti Basyarnas.

Penyelesaian sengketa melalui Basyarnas bersifat rahasia (confidential). Sebelum pemeriksaan sengketa dimulai, arbiter harus terlebih dahulu mendamaikan para pihak yang bersengketa. Apabila perdamaian (islab) tercapai, maka arbiter akan mencatatnya sebagai kesepakatan bersama yang mengikat dan harus dipatuhi oleh para pihak yang bersengketa. Namun, apabila perdamaian tidak tercapai, maka pemeriksaan dilanjutkan sesuai dengan peraturan yang berlaku. Sengketa harus selesai dalam waktu enam bulan. ${ }^{9}$ Putusan yang diberikan arbiter bersifat final dan mempunyai kekuatan hukum tetap dan mengikat para pihak yang bersengketa (Pasal 60 UU No. 30 Tahun 1999). Putusan Basyarnas ini, sesuai dengan Pasal 59 ayat (1) UU No. 30 Tahun 1999, didaftarkan oleh arbiter atau kuasa hukumnya kepada Panitera Pengadilan Negeri. Apabila ada salah satu pihak yang bersengketa enggan melaksanakan putusan arbitrase secara sukarela, maka pihak lainnya bisa mengajukan permohonan eksekusi kepada Ketua Pengadilan Negeri dengan mendaftarkan permohonan tersebut kepada Panitera Pengadilan Negeri (Pasal 61 dan 62 UU No. 30 Tahun 1999).

\footnotetext{
7 Jurnal Konstitusi, Menegaskan Kompetensi Pengadilan Agama, Edisi No.79-September 2013.

8 Putusan MK Nomor 93/PUU-X/2012, diberlakukan tanggal 29 Agustus 2013.

${ }_{9}$ Abdul Rasyid, Eksekusi Putusan Badan Arbitrase Syariah Nasional, Published 07 Maret 2015.
} 
Sengketa merupakan fenomena terjadinya konflik atau perselisihan yang tidak dapat dihindari dalam kehidupan sehari-hari. Selama interaksi antar manusia terjalin, potensi timbulnya sengketa akan tetap ada karena cara pandang yang berbeda. Seiring dengan tumbuh kembangnya aktivitas ekonomi, timbul berbagai macam bentuk kerjasama yang semakin kompleks dalam berbisnis. Pada sektor bisnis syariah misalnya, tidak menutup kemungkinan untuk terjadinya sengketa.

Pada umumnya, sengketa dapat terjadi karena adanya penipuan atau ingkar janji. Salah satu pihak dapat dikatakan ingkar janji atau tidak memenuhi prestasi (wanprestasi) jika pihak tersebut tidak melaksanakan prestasi sama sekali, melaksanakan prestasi tetapi tidak sesuai dengan yang diperjanjikan, melaksanakan prestasi tetapi terlambat atau tidak tepat waktu, dan melaksanakan hal-hal yang dilarang dalam perjanjian. ${ }^{10}$

Sengketa bisnis syariah khususnya timbul ketika terjadi konflik/pertentangan yang terjadi antar para pihak (baik badan hukum/perseorangan) dalam transaksi bisnis syariah sehingga menimbulkan kerugian. Dalam kegiatan bisnis tentunya diharapkan akan mendatangkan keuntungan para pihak sesuai dengan asas kesepatakan. Namun demikian apa yang telah mereka sepakati, terkadang menimbulkan sengketa yang tentunya akan mendatangkan kerugian salah satu pihak. Untuk menegakkan hak-hak para pihak tersebut, maka terdapat dua jalan yang bisa ditempuh oleh para pihak, yaitu melalui jalur pengadilan atau melalui musyawarah. Tetapi ilmu hukum mempunyai alternatif lain yaitu melalui suatu lembaga yang dinamakan Arbitrase. ${ }^{11}$

Choice of forum merupakan hal yang penting terkait penyelesaian sengketa. Masing-masing pihak yang bersengketa jika tidak dapat menyelesaikan sengketanya secara musyawarah, hal ini pun bisa ditindak melalui proses hukum. Pada Pasal 1244 BW telah dijelaskan bahwa debitur harus dihukum untuk mengganti biaya

${ }^{10}$ Abdul Ghofur Anshori, Penyelesaian Sengketa Perbankan Syariah: Analisis Konsep dan UU No.21 Tahun 2008 (Yogyakarta: Gadjah Mada University Press, 2010), hlm.35-36.

11 Richard Burton Simataupang, Aspek Hukum Dalam Bisnis, cet.ke-2 (Jakarta: PT. Rineka Cipta, 2003), hlm. 41 . 
kerugian jika debitur tidak memenuhi perikatan dengan tepat waktu, dan ada sebab tak terduga yang tidak dapat dipertanggungjawabkan pada debitur. ${ }^{12}$ Penyelesaian sengketa tersebut dapat dilakukan melalui jalur litigasi (pengadilan) atau nonlitigasi (di luar pengadilan), hal ini menjadi choice of law dari masing-masing pihak yang bersengketa.

Adanya putusan MK Nomor 93/PUU-X/2012, menimbulkan pertanyaan mengenai pengadilan mana yang berwenang untuk mengeksekusi putusan Basyarnas ketika ada para pihak yang bersengketa tidak melaksanakan putusan secara sukarela. Sebenarnya untuk mengatasi masalah ini, Mahkamah Agung telah mengeluarkan Surat Edaran Nomor 08 Tahun 2008 tentang Eksekusi Putusan Badan Arbitrase Syariah. Angka 4 surat edaran ini secara tegas menyatakan bahwa dalam hal putusan Badan Arbitrase Syariah tidak dilaksanakan secara sukarela, maka berdasarkan permohonan salah satu pihak yang bersengketa, Ketua Pengadilan Agamalah yang berwenang mengeksekusi putusan Badan Arbitrase Syariah. Akan tetapi berlakunya SEMA ini tidak bertahan lama. Dengan direvisinya Undang-Undang No. 4 Tahun 2004 dengan Undang-Undang No. 48 Tahun 2009 tentang Kekuasaan Kehakiman, Pasal 59 UU ini dalam penjelasannya secara jelas menyatakan bahwa eksekusi putusan arbitrase, termasuk arbitrase syariah, dilaksanakan berdasarkan perintah Ketua Pengadilan Umum. Kemudian berdasarkan Pasal 59 Undang-Undang No. 48 Tahun 2009 tentang Kekuasaan Kehakiman ini, bulan Mei 2010, Mahkamah Agung mengeluarkan SEMA No. 8 Tahun 2010 tentang Penegasan Tidak Berlakunya Surat Edaran Mahkamah Agung Nomor 08 Tahun 2008 tentang Eksekusi Putusan Arbitrase Syariah.

Sampai saat ini, aturan yang dijalankan Basyarnas baik secara konseptual maupun implementasi masih merujuk pada UU Nomor 30 Tahun 1999 tentang Arbitrase dan Alternatif Penyelesaian Sengketa. Undang-undang ini menjadi pokok penerapan lembaga arbitrase di Indonesia. Antara Basyarnas yang menggunakan

\footnotetext{
hlm.329.

${ }^{12}$ Kitab Undang-Undang Hukum Perdata Dilengkapi UU Advokat, cet.ke-5 (Bandung: Citra Umbara, 2011),
} 
konsep syariah dalam menyelesaikan perkaranya berbeda secara filosofis dengan aturan yang ada dalam UU arbitrase tersebut. Akibatnya menimbulkan persoalan, salah satunya adalah kewajiban basyarnas mendaftarkan putusannya ke Pengadilan Negeri.

Persoalan lain yakni tentang pembatalan putusan Basyarnas, seperti pada contoh kasus penyelesaian sengketa di basyarnas antara PT Bank Syariah Mandiri melawan Termohon PT Atriumasta Sakti. Penyelesaian sengketa itu telah sampai pada putusan basyarnas. Terhadap putusan Basyarnas tersebut dimohonkan pembatalan putusan ke Pengadilan Agama (PA) Jakarta Pusat oleh PT. Bank Syariah Mandiri pada tanggal 10 November 2009 dengan dasar ketentuan Pasal 70 UU Nomor 30 Tahun 1999. Melalui Perkara Nomor 792/Pdt.G/2009/PA.JP tanggal 10 Desember 2009, PA Jakarta Pusat mengabulkan permohonan ini dan membatalkan putusan Basyarnas. Sampai pada kasasi, putusan PA Jakarta Pusat tersebut dibatalkan oleh putusan kasasi MA Nomor 188/K/AG/2010 yang dijatuhkan pada tanggal 9 Juni 2010. Putusan Kasasi ini juga menyatakan Pengadilan Agama tidak berwenang menangani perkara pembatalan putusan Basyarnas dengan pertimbangan Pasal 71 UU Nomor 30 Tahun 1999 yakni pembatalan putusan basyarnas harus diajukan ke Pengadilan Negeri. ${ }^{13}$

Dari kasus tersebut tampak jelas persoalan kompetensi Pengadilan Agama sebagai satu-satunya perngadilan yang berwenang dalam menyelesaikan sengketa ekonomi syariah berdasar pada pasca putusan MK Nomor 93/PUU-X/2012ternyata tidak mudah direalisasikan karena adanya UU Nomor 30 Tahun 1999 yang membatasi kompetensi absolut Pengadilan Agama. Berkaitan dengan hal ini, untuk mengantisipasi adanya persoalan kasus yang sama maka diperlukan penelitian terkait dualisme peraturan tentang eksekusi putusan Basyarnas.

${ }^{13}$ Direktori Putusan MA RI Nomor 404/PDT.G/2013/PN.JKT.PST. 


\section{PEMBAHASAN}

Secara yuridis penegakan hukum hanya dilakukan oleh kekuasaan kehakiman (judicial Power) yang secara konstitusional lazim disebut badan yudikatif (Pasal 24 UUD 1945). Dengan demikian, maka yang berwenang memeriksa dan mengadili sengketa hanya badan peradilan yang bernaung di bawah kekuasaan kehakiman yang berpuncak di Mahkamah Agung. Pasal 2 UU No. 14 Tahun 1970 secara tegas menyatakan bahwa yang berwenang dan berfungsi melaksanakan peradilan hanya badan-badan peradilan yang dibentuk berdasarkan undang-undang. Di luar itu tidak dibenarkan karena tidak memenuhi syarat formal dan official serta bertentangan dengan prinsip under the authority of law. Namun berdasarkan Pasal 1851,1855,1858 KUHP,Penjelasan Pasal 3 UU No. 14 Tahun 1970 serta UU No. 30 Tahun 1999 tentang Arbitrase dan Alternatif Penyelesaian Sengketa, maka terbuka kemungkinan para pihak menyelesaikan sengketa dengan menggunakan lembaga selain pengadilan (non litigasi), seperti arbitrase atau perdamaian (islab). ${ }^{14}$

Secara administrasi, semua peradilan di Indonesia baik Pengadilan Agama, Pengadilan Negeri, Pengadilan Militer mapun Pengadilan Tata Usaha Negara berada di bawah Mahkamah Agung. Setiap peradilan tersebut memiliki kewenangan masing-masing dalam menyelesaikan perkara. Kewenangan untuk melaksanakan tugas pokok pengadilan tersebut dibagi dua yaitu: Pertama, kewenangan relatif atau kompetensi relatif yaitu kewenangan untuk menerima, memeriksa, dan mengadili serta menyelesaikan suatu perkara yang diajukan kepadanya, didasarkan kepada wilayah hukum pengadilan mana tergugat bertempattinggal. ${ }^{15}$ Berdasarkan ketentuan pasal 4 Undang-Undang Nomor 7 Tahun 1989 yang diperbaharui dengan Undang-Undang Nomor 3 Tahun 2006, menyatakan bahwa wilayah hukum Pengadilan Agama adalah meliputi wilayah kotamadya atau kabupaten, sedangkan untuk Pengadilan Tinggi Agama wilayah

\footnotetext{
${ }^{14}$ Karnaen Perwataatmaja, dkk., Bank dan Asuransi Islam di Indonesia, (Jakarta: Prenada Media, 2005), hlm. 288. 4 A. Rahmat Rosyadi, Arbitrase dalam Perspektif Islam dan Hukum Positif, (Bandung: Citra Aditya Bakti, 2002), hlm. 43.

${ }^{15}$ Maksudnya adalah yang berwenang mengadili adalah Pengadilan Agama tempat tinggal tergugat, Baca Retnowulan Sutantio, Hukum Acara Pedata Dalam Teori dan Praktek,(Bandung: Mandar Maju, 1989), hlm. 8.
} 
hukumnya meliputi wilayah Propinsi. Kedua, kewenangan mutlak atau kompensasi absolut adalah wewenang badan peradilan dalam memeriksa jenis perkara tertentu yang mutlak tidak dapat diperiksa oleh badan peradilan lain. Kewenangan mutlak ini untuk menjawab pertanyaan, apakah perkara tertentu, misalnya sengketa

Sebelum adanya Putusan MK Nomor 93/PUU-X/2012, terjadi perdebatan panjang dlam banyak kalangan mengenai peradilan mana yang berwenang menyelesaikan perselisihan jika terjadi sengketa syariah. Apakah menjadi kewenangan Pengadilan Umum atau Pengadilan Agama. Amandemen UndangUndang Nomor 7 Tahun 1989 memberikan wewenang kekuasaan Peradilan Agama bertambah luas, yang semula sebagaimana diatur dalam Pasal 49 Undang-Undang Nomor 7 tahunm 1989 hanya bertugas dan berwenang memeriksa, memutus, dan menyelesaikan perkara ditingkat pertama antara orang-orang yang beragama Islam di bidang : a) perkawinan, b) kewarisan, wasiat dan hibah yang dilakukan berdasarkan hukum Islam, dan c) wakaf dan shadaqah.

Dengan adanya amandemen Undang-Undang tersebut, maka ruang lingkup tugas dan wewenang Peradilan Agama diperluas. Berdasarkan Pasal 49 huruf (i) UU No. 3 Tahun 2006 Pengadilan Agama bertugas dan berwenang memeriksa, mengadili dan menyelesaikan perkara ditingkat pertama antara orang-orang yang beragama Islam dalam bidang ekonomi syariah yang meliputi: a) bank syariah, b) lembaga keuangan mikro syariah, c) asuransi syariah, d) reasuransi syariah, e) reksa dana syariah, f) obligasi syariah dan surat berharga berjangka menengah syariah, g) sekuritas syariah, h) pembiayaan syariah, i) pegadaian syariah, j) dana pensiun lembaga keuangan syariah,dan k) bisnis syariah. ${ }^{16}$ Dalam penjelasan Pasal tersebut antara lain dinyatakan:

"Yang dimaksud dengan "antara orang-orang yang beragama Islam" adalah termasuk orang atau badan bukum yang dengan sendirinya menundukean diri dengan sukarela kepada bukum Islam mengenai hal-hal yang menjadi kewenangan Pengadilan Agama sesuai ketentuan pasal ini." 
Dari penjelasan Pasal 49 tersebut, maka seluruh nasabah lembaga keuangan dan lembaga pembiayaan syariah, atau bank konvensional yang membuka unit usaha syariah dengan sendirinya terikat dengan ketentuan ekonomi syariah, baik dalam pelaksanaan akad maupun dalam penyelesaian perselisihan. Adapun sengketa di bidang ekonomi syariah yang menjadi kewenangan Pengadilan Agama adalah ${ }^{17}$ :

1. Sengketa di bidang ekonomi syariah antara lembaga keuangandan lembaga pembiayaan syariah dengan nasabahnya

2. Sengketa di bidang ekonomi syariah antara sesama lembagakeuangan dan lembaga pembiayaan syariah

3. Sengketa di bidang ekonomi syariah antara orang-orang yang beragama Islam, yang mana akad perjanjiannya disebutkan dengan tegas bahwa kegiatan usaha yang dilakukan adalah berdasarkan prinsip-prinsip syariah

Penjelasan Pasal 49 diatas menegaskan kewenangan untuk menyelesaikan sengkete Ekonomi Syari'ah merupakan kewenangan absolute Pengadilan Agama. Namun demikian timbul ketidakpastian hukum ketika memahami UU Nomor 21 Tahun 2008 tentang perbankan syariah. Khusus pada Pasal 55 ayat (2) disebutkan dalam penjelasan, bahwa yang dimaksud dengan isi akad adalah melalui upaya sebagai berikut: a. musyawarah, b. mediasi perbankan, c. melalui Badan Arbitrase Syariah Nasional (Basyarnas) atau lembaga arbitrase lain dan/atau, d. melalui pengadilan dalam lingkungan peradilan umum. Pada poin (d) inilah yang diajukan judicial review ke Mahkamah Agung, bahwa terdapat kata peradilan umum. Hal ini bertentangan dengan Pasal 55 ayat (1) UU No. 21 Tahun 2008 yang menyatakan bahwa penyelesaian sengketa perbankan syariah dilaksanakan dalam lingkup peradilan Agama.

Dalam UU Perbankan Syariah hanya menyebutkan Basyarnas atau arbitrase lain (BANI) sebagai lembaga yang menjadi pilihan hukum para pihak ketika terjadi sengketa, tidak sampai dijelaskan pada eksekusi putusan. Sehingga tidak cukup

17 Abdul Manan, Beberapa Masalah Hukum dalam Praktek Ekonomi Syariah, Makalah Diklat Calon Hakim Angkatan-2 di Banten, 2011, hlm.8 
menjadi rujukan utama dalam hal berperkara di Basyarnas. Berbeda dengan apa yang diatur dalam UU No.30 Tahun 1999 tentang Arbitrase dan Alternatif Penyelesaian Sengketa yang menjadi landasan hukum berperkara Basyarnas. Hal ini didasarkan pada UU No.48 Tahun 2009 tentang Kekuasaan Kehakiman Pasal 59, disebutkan dalam penjelasan Pasal 59 tersebut yang dimaksud dengan "arbitrase” dalam ketentuan ini termasuk juga arbitrase syariah (Basyarnas). Jadi jelaslah bahwa UU No.30 Tahun 1999 juga digunakan sebagai landasan hukum Basyarnas.

Pilihan hukum sengketa ekonomi syariah diatur dalam UU Nomor 21 Tahun 2008 Tentang Perbankan Syariah. Dalam Pasal 55 dapat dikelompokkan bahwa pilihan hukum memuat dua lembaga, yakni lembaga peradilan dan non peradilan. Lembaga peradilan-setelah di judicial review oleh MK-hanya Peradilan Agama yang berwenang menyelesaikan sengketa ekonomi syariah. ${ }^{18}$ Sedangkan lembaga non peradilan terbagi lagi menjadi dua pilihan, yakni Badan Arbitrase Nasional Indonesia (BANI) dan Basyarnas. Selanjutnya dijelaskan pada pasal 55 ayat (3) bahwa penyelesaian sengketa tersebut tidak boleh bertentangan dengan prinsip syariah.

Dari sini terlihat bahwa terdapat beberapa alternatif dalam penyelesaian sengketa ekonomi syariah. Para pihak yang tidak menuangkan klausul perjanjian dalam akad, maka secara otomatis sengketa ekonomi syariah menjadi wewenang Pengadilan Agama. Ini didasarkan pada UU Nomor 3 Tahun 2006 Jo UU Nomor 50 Tahun 2009 dan UU Nomor 21 Tahun 2008 Pasal 55 ayat (1), karena sengketa ekonomi syariah telah menjadi kewenangan absolut dari Pengadilan Agama seperti yang diatur dalam undang-undang tersebut. Jadi, sengketa ekonomi syariah yang dilakukan di Pengadilan Agama bukan termasuk dari suatu pilihan hukum/choice of forum. Dengan kata lain, Pengadilan tidak perlu dipilih karena sudah jelas terdapat dalam undang-undang.

18 Berdasarkan Putusan MK Nomor 93/PUU-X/2012. 
Choice of Forum berlaku hanya bagi para pihak yang menginginkan penyelesaian sengketa ekonomi syariah dilakukan di luar pengadilan, yakni terdapat dua pilihan hukum; BANI, Basyarnas, atau Badan Arbitrase lain. Selanjutnya untuk memilih badan arbitrase, kesepakatan dapat dibagi dua, yakni acta de compromittendo (sudah masuk dalam klausul). Misalnya apabila terjadi sengketa maka para pihak memilih penyelesaiannya adalah Basyarnas Cabang Yogyakarta. Sedangkan dan acta compromi (penunjukkan terjadi setelah adanya sengketa/tidak disebut dalam akad). Jika tidak disebut dalam akad, inilah yang menjadi wewenang Pengadilan Agama. Namun apabila dalam perjalanannya terjadi masalah, para pihak boleh memilih agar sengketa diselesaikan di Basyarnas, dengan syarat dibuatkan kesepakatan baru. Kesepakatan baru dibuat sebagai addendum yang melekat dari akad sebelumnya.

Basyarnas dalam hal ini tidak mempunyai wewenang menyelesaikan sengketa ekonomi syariah jika tidak dibuat kesepakatan berupa addendum. Karena salah satu syaratnya adalah arbitrase haruslah ada yang ditunjuk. Ini baru kesepakatan forum memilih basyarnas sebagai badan arbitrase yang ditunjuk untuk menangani sengketa ekonomi syariah. Setelah ini ditindaklanjuti melalui kesepakatan para pihak yang bersengketa, yakni dengan membuat pernyataan resmi bahwa Basyarnas yang ditunjuk adalah Basyarnas Cabang Yogyakarta, misalnya. Dengan ini, Basyarnas sudah berhak menangani sengketa sehingga para pihak tidak lagi perlu membuat surat permohonan yang diajukan pada Basyarnas.

Basyarnas atau arbitrase memiliki beberapa kelebihan dibanding penyelesaian sengketa di pengadilan. Pada prinsipnya sifat putusan Basyarnas ini final dan mengikat. Yang dimaksud final adalah putusan ini pada tingkat pertama dan terakhir artinya tidak ada lagi upaya hukum dalam bentuk apapun(buku). Singkatnya, jika siang ini diputuskan maka sorenya dapat dieksekusi karena sudah mengikat. Putusan dianggap inchracht (berkekuatan hukum tetap). Proses akhirnya menjadi singkat, biaya pun menjadi efisien. Dalam dunia bisnis, hal-hal yang efisien 
lebih diminati karena para pihak akan memperhatikan bagaimana agar usahanya menguntungkan dengan cara se-efisien mungkin. Cari penelitian di Amerika yang

Secara esensinya para pihak yang bersengketa dalam kaitannya dengan ekonomi atau bisnis syariah dilakukan di Pengadilan Agama ${ }^{19}$, tetapi apabila para pihak menginginkan sengketa tersebut diselesaikan di lembaga non peradilan maka secara otomatis tunduk pada UU Nomor 30 Tahun 1999. Konsep UU Nomor 30 Tahun 1999 secara eksplisit disebutkan pada Pasal 62 mengenai perintah agar putusan arbitrase didaftarkan eksekusinya di Pengadilan Negeri. (buku: putusan basyarnas tidak punya fiat ekskusi)

Dalam proses beracara, Basyarnas dan Peradilan Agama menggunakan sumber hukum Islam. Berbeda dengan BANI yang proses beracaranya masih dalam ranah sumber hukum positif. Sehingga jika para pihak melaksanakan akad/perjanjian tentang bisnis syariah, untuk penyelesaiannya dapat dipilih melalui lembaga Basyarnas atau Peradilan Agama.

Sewajarnya jika para pihak berakad dengan akad syariah, dalam perjalanannya sampai dengan penyelesaiannya pun diharapkan on the track, yakni sesuai dengan prinsip syariah. Hal ini sesuai dengan yang dikatakan oleh Dr.Abdul Jamil, S.H., M.H. ${ }^{20}$ Dalam hal para pihak memilih untuk menyelesaikan sengketa di Basyarnas, hingga tahap akhir yakni dibacakannya putusan oleh arbiter terdapat keberatan dari salah satu pihak. Keberatan dengan putusan Basyarnas oleh karena beberapa hal dapat diajukan pembatalan putusan, sebab diduga adanya:

1. surat atau dokumen yang diajukan dalam pemeriksaan, setelah putusan dijatuhkan, diakui palsu atau dinyatakan palsu;

2. setelah putusan diambil ditemukan dokumen yang bersifat menentukan, yang disembunyikan oleh pihak lawan; atau

\footnotetext{
19 Pasal 55 Ayat (1) UU Nomor 21 Tahun 2008.

20 Dosen Hukum Penyelesaian Sengketa Bisnis Syariah dan praktisi hukum; Advokat dan Arbiter di Basyarnas cabang Yogyakarta.
} 
3. putusan diambil dari hasil tipu muslihat yang dilakukan oleh salah satu pihak dalam pemeriksaan sengketa. ${ }^{21}$

Pembatalan putusan jika merujuk pada UU Nomor 30 Tahun 1999 Tentang Arbitrase, maka dapat dilakukan di Pengadilan Negeri. Di sini tentu mengandung perbedaan sumber hukum dalam proses beracara. Sumber hukum yang digunakan oleh Pengadilan Negeri berbeda dengan yang digunakan oleh Basyarnas. (buku: sumber hukum yang digunakan PN dalam proses beracara)

Dari perbedaan sumber hukum yang digunakan, besar kemungkinan akan melahirkan hasil putusan yang berbeda pula tentu putusan dapat bertentangan dengan prinsip awal yakni prinsip syariah. Menurut Narasumber, Dr. Abdul Jamil, S.H., M.H, dalam hal pembatalan putusan yang dilaksanakan di PN orang dapat membantah karena hakim PN pun dapat menggunakan metode penemuan hukum, namun sejauh ini belum ada menurut beliau hakim PN yang menggunakan Hukum Islam melalui metode penemuan hukum.

\section{PENUTUP}

Prosedur beracara BASYARNAS masih merujuk pada UU Nomor 30 Tahun 1999 tentang ADR. Dualisme eksekusi putusan BASYARNAS terjadi karena adanya UU Nomor 30 Tahun 1999 yang membatasi kompetensi absolut Pengadilan Agama sebagai lembaga yang berwenang menyelesaikan sengketa ekonomi syariah. Adanya tumpang tindih kewenangan atau dualisme peraturan antara UU Nomor 21Tahun 2008 dengan UU Nomor 48 Tahun 2009 menunjukkan bahwa telah terjadi dualisme karena adanya peraturan yang baru tidak merujuk pada peraturan lama dan telah mengabaikan asas pembentukan peraturan perundang-undangan yang baik. Hal disebabkan karena teori sinkronisasi peraturan perundang-undangan yang bertujuan untuk melihat adanya keselarasan antara peraturan yang satu dengan peraturan lainnya tidak diterapkan dalam Pasal 61 UU Nomor 30 Tahun 1999, Pasal 55 (1) UU Nomor 21 Tahun 2008, dan Pasal 
59 UU Nomor 48 Tahun 2009. Dalam pembuatan Pasal 59 UU Nomor 48 Tahun 2009 yang merupakan lex specialis dari Pasal 55 (1) UU Nomor 21 Tahun 2008 tidak mengkaji pada UU Nomor 21 Tahun 2008 khususnya ketetapan mengenai pelaksanaan putusan arbitrase. Untuk mengatasi adanya dua dalil atau aturan yang bertentangan (Ta'arud\} al-adillah) dapat dilakukan melalui metode tarjih (menguatkan) dan al jam'u wa al-taufiq, yakni dengan cara mengkompromikan dua dalil atau aturan yang bertentangan tersebut. Dengan metode tarjih bisa diketahui bahwa PA lebih berwenang mengeksekusi putusan BASYARNAS, karena sengketa dari para pihak di BASYARNAS adalah mengenai ekonomi syariah. Hal ini dikuatkan dengan adanya PERMA Nomor 14 Tahun 2016 khususnya di Pasal 13.

Hukum yang hidup dimasyarakat sebagai alat rekayasa sosial, lain halnya dengan hukum yang sudah dipositifkan yakni bertujuan untuk menciptakan keadilan yang berkepastian hukum. Sedangkan adanya kepastian hukum adalah untuk menjamin nilai-nilai keadilan dalam hukum tercapai. Akibat dualisme peraturan eksekusi putusan BASYARNAS menyebabkan ketidakpastian hukum yang akan berimbas pada ketidakadilan. Selama ini keberlakuan hukum yang digunakan oleh BASYARNAS sebagai standar acuan dalam proses menyelesaikan sengketa memang masih menggunakan UU Nomor 30 Tahun 1999 Tentang Arbitrase dan Alternatif Penyelesaian Sengketa, khususnya masalah kewenanangan dalam eksekusi putusan BASYARNAS yang harus dilakukan oleh Pengadilan Negeri. Selain itu juga, UU Arbitrase ini pun sudah tidak lagi mengikuti perkembangan zaman dan tidak sejalan dengan perkembangan hukum yakni UU No.21 Tahun 2008 Tentang Perbankan Syariah dan UU No.3 Tahun 2006 Jo UU No.50 Tahun 2009 Tentang Peradilan Agama. Berdasarkan UU Peradilan Agama yang merupakan produk legislasi pertama memberikan kompetensi kepada Pengadilan Agama dalam menyelesaikan sengketa ekonomi syariah dan adanya UU Perbankan syariah untuk memperkuat wewenang PA, khusunya dalam hal sengketa pada perbankan syariah, semestinya Peradilan Agama sudah secara praktis memiliki 
kompetensi Peradilan Agama dalam menyelesaikan sengketa ekonomi syariah. Meskipun demikian, masih saja terjadi perdebatan dalam kaitannya dengan wewenang mengkeksekusi putusan sengketa ekonomi syariah. Seperti yang disampaikan Achmad Ali dalam bukunya keterpurukan hukum di Indonesia, secara universal jika ingin keluar dari situasi keterpurukan hukum, maka harus membebaskan diri dari belenggu formalisme-positivisme, karena jika hanya mengandalkan pada teori atau pemahaman hukum secara legalistik-positivistis yang hanya berbasis pada peraturan tertulis belaka, maka tidak akan pernah mampu untuk menangkap hakikat kebenaran, keadilan, dan kemanusiaan. Usaha pembebasan dan pencerahan tersebut dapat dilakukan dengan mengubah cara kerja yang konvensional (diwariskan oleh mazhab hukum positif) dengan segala doktrin dan prosedurnya yang serba formal tersebut menuju pencerahan 


\section{DAFTAR PUSTAKA}

Abdurrahman, Muslim, Sosiologi dan Metode Penelitian Hukum, Malang: Universitas Muhammadiyah Malang Press, 2009.

Arif, Muhammad "Respon Basyarnas Perwakilan Daerah Istimewa Yogyakarta Terhadap Kewenangan Pengadilan Agama”, Yogyakarta: Universitas Sunan Kalijaga, 2008.

Anshori, Abdul Ghofur, Penyelesaian Sengketa Perbankan Syariah: Analisis Konsep dan UU No.21 Tabun 2008, Yogyakarta: Gadjah Mada University Press, 2010.

Gunawan Widjaya dan Ahmad Yani, Hukum Arbitrase, Jakarta: PT Raja Grafindo Persada, 2000.

Hartini, Rahayu, “Kedudukan Fatwa MUI mengenai Penyelesaian Sengketa Melalui Basyarnas Pasca Lahirnya UU No. 3 Tahun 2006 Tentang Pengadilan Agama”, Malang: Univesitas Muhammadiyah Malang, 2007.

Hayat, Jihadul, and Refky Fielnanda. "Peradilan Agama Era Reformasi Kedua Setelah Berlakunya Undang-Undang Nomor 3 Tahun 2006 Tentang Peradilan Agama."

Hervina, Kontroversi Kewenangan Pengadilan Negeri dan Pengadilan Agama Dalam Menyelesaikan Sengketa Perbankan Syariah di Indonesia, www. Badilag.net.

Ibn Syu'aib al-Nasa'i, Abdurrahman, Bab Idza Hakamu Rajulan Faqadha Bainahum”, Beirut: Dar al-Ma'rifah, Juz VIII, 1138 H.

Jurnal Konstitusi, Menegaskan Kompetensi Pengadilan Agama, Edisi No.79-September 2013. 
Kitab Undang-Undang Hukum Perdata Dilengkapi UU Advokat, Bandung: Citra Umbara, cet.ke-5 2011.

Manan, Abdul, Hukum Ekonomi Syariah (Dalam Perspektif Kewenangan Peradilan Agama), Jakarta: Prenada Media Group, 2014.

Marzuki, Peter Mahmud, Pengantar Ilmu Hukum, Kencana: Jakarta, 2008

Nafis, M. Cholis, Teori Hukum Ekonomi Syariah, Jakarta: UI Press, 2011.

Pratiwi, Dian, "Penolakan Pembatalan Putusan Badan Arbitrase Syariah Nasional (Basyarnas) Dalam Sengketa Perbankan Syariah (Studi Putusan Mahkamah Agung No. 188 K/AG/2010)", Lampung: Universitas Lampung, 2016.

Putusan MK Nomor 93/PUU-X/2012.

Rasyid, Abdul, Eksekusi Putusan Badan Arbitrase Syariah Nasional, Published 07 Maret 2015.

Syahbudin, Aries, "Penerapan Arbitrase sebagai Penyelesaian Sengketa di Bank Syariah Melalui Badan Arbitrase Syariah Nasional (Basyarnas)", Yogyakarta: Universitas Islam Indonesia, 2008.

Shihab, M. Quraish, Tafsir Al-Misbah; Pesan, Kesan, dan Keselarasan Al-Qur'an, Jakarta: Lintera Hati, jilid 13, 2002.

Simatupang, Richard Burton, Aspek Hukum Dalam Bisnis, Jakarta: PT. Rineka Cipta, cet.ke-2, 2003.

Sofiana, Ratna, "Implikasi Tugas dan Wewenang Badan Arbitrase Syariah Nasional Dalam Penyelesaian Sengketa Ekonomi Syariah Pasca Putusan MK No. 93/PUU-X/2012 Tentang Pengujian Konstitusional UU No. 21 Tahun 2008 Tentang Perbankan Syariah”, Yogyakarta: UIN Sunan Kalijaga, 2015.

Sumitro, Warkum, Asas-asas Perbankan Islam dan Lembaga-lembaga Terkait (BMUI \& Takaful) di Indonesia, Jakarta: Rajawali Press, 1996. 
Sutiyoso, Bambang, Hukum Arbitrase dan Alternatif Penyelesaian Sengketa, Yogyakarta: Gama Media, 2008.

Talli, Abdul Halim, Lembaga Tabkim, Jurnal Ar-Risalah vol.10 nomor 2: 2010.

Tehedi, "Implementasi Penyelesaian Sengketa Bisnis Syariah di Basyarnas Perwakilan Yogyakarta (Studi Terhadap Penerapan Sifat Final dan Binding)", Yogyakarta: UIN Sunan Kalijaga, 2013.

UU Nomor 7 Tahun 1989 jo UU Nomor 3 Tahun 2006 jo UU Nomor 50 Tahun 2009 Tentang Peradilan Agama.

UU Nomor 48 Tahun 2009 Tentang Kekuasaan Kehakiman.

UU Nomor 30 Tahun 1999 Tentang Arbitrase dan Alternatif Penyelsaian Sengketa.

UU Nomor 21 Tahun 2008 Tentang Perbankan Syariah. 